\section{Unfair on DeVita}

SIR - The recent US Senate hearings in which Dr Vincent DeVita was scourged for the failure of the NIH-NCI bureaucracy to vitiate promptly an accused laboratory cheat leaves one appalled and apprehensive. Dr DeVita is the first NCI director who is a clinical oncologist, an occupation faced with the unenviable repetitive experience of patients who become progressively worse, mortify and die. In no small part due to the efforts of Dr DeVita and the organization he has assembled, this no longer takes the invariable course it once did and the concept of a cure has become realistic for many cancer patients. He has tried to redirect the cancer research industry back to the human cancer patient and away from highvisibility science for science's sake, while still juggling the all important basic research that must be done as well. To hear of his being chastized in such a silly way can be best compared to rejecting Socratic reasoning because Socrates may have been bald.

CECII. H. FOX

Silver Spring,

Maryland, USA

\section{Serbian exchange}

SiR - We would like to report on the great value of a recent exchange visit between British and Yugoslav geologists. In May we took part in a ten-day field trip to Yugoslavia, organized jointly as part of an agreement between the Royal Society of London and the Council of Academies of Science and Arts of the Federative Socialist Republic of Yugoslavia. It followed a visit in autumn 1980 when Yugoslav geologists Professor V. Majer and S. Karamata came to the UK, the first time that such an exchange had occurred between geologists of these countries.

Our time was spent in Yugoslavia mostly on a geological excursion through Serbia by minibus organized by Professor S. Karamata of the Faculty of Mining and Geology at Belgrade University. A round trip of over $2,100 \mathrm{~km}$ was made, starting from Belgrade and passing through the Carpatho-Balkan chain, the Serbo-Macedonian massif and the Inner and eastern Outer Dinarides. Stops were made at selected localities of interest enabling the international team of British, French, Hungarian and Yugoslav geologists to exchange ideas and collect rock samples. The lithology observed ranged from Palaeozoic basement, Mesozoic lavas and sediments and Cenozoic calc-alkaline flows to ultramafic, mafic and metamorphic components of ophiolites and related olistostromes.

This traverse enabled us to obtain an excellent introduction to the geology of Yugoslavia - an essential part of studies in the Earth sciences where it is necessary to observe at first hand natural phenomena in the field. We hope this initial exchange will lead to further visits and joint research in the near future.

S. O. Agre:li.

A. G. SNITH

J. G. Spray

Department of Earth Sciences, University of Cambridge, $U K$

\section{Human protection}

$\mathrm{S}_{\mathrm{IR}}$ - An imprecise reference in a recent article, "NIH censure for Dr Martin Cline," (Nature 4 June, p.269) prompts us to delineate the distinction between the UCLA School of Medicine Human Subject Protection Committee which reviews research protocols involving human subjects for risk-benefit ratio and the UCLA Human Subject Policy Committee which, based on federal regulations, develops university policy governing research involving human subjects.

ESTHER F. HAYS

Human Subject Protection Commitiee, School of Medicine,

University of California, Los Angeles, USA

\section{Fight the obscure}

SIR - Recognizing the present popularity of various forms of anti-scientific obscurantism, both here and still more in his own country, Dr Ralph Lewis was dead right to conclude his letter (Nature 11 June, p.448): "We must find and state clearly our fundamental agreements, so that our differences in presentation cannot be misconstrued and distorted"

I suggest that one first necessary step is to insist always that the contrary of any evolutionary account of the origin of species is a doctrine of special creation. Evolution in this understanding would be decisively refuted were palaeontologists to discover fossil remains of creatures morphologically indistinguishable from the higher mammals in rocks which are much too old - J.B.S.

Haldane used to specify human remains in a coal seam. Darwinian and any alternative accounts of the mechanism of such evolution, or of its mechanisms - the Lamarckian inheritance of acquired characteristics, for instance - must all be equally inconsistent with any doctrine of special creation. And, although I will not myself pretend to understand cladistics, we can be sure that its Marxist adherents are not rooting for special creation as opposed to evolution. Their point against Darwin is, surely, that while he defended "that old canon in natural history, Natura non facit saltum', they themselves are committed to the opposite contention, that both Nature and humanity sometimes take "A great leap forward".

A second step is to dispose of certain philosophical muddles and misconceptions such as those propagated by the British Museum (Natural History). Barry Cox quoted several in his report (Nature 4 June, p.373). One is that the assertion of the survival of the fittest is vacuously tautological: "The Survival of the Fittest is an empty phrase, it is a play upon words". Certainly, since the criterion of fitness to survive is here actual survival, this assertion is not to be construed as an assurance that all is for the best. It is, nevertheless, not a tautology. For clearly it denies that the survivors survive at random, while asserting that they have some sort of competitive edge over the non-survivors.

Again, Cox quotes the statement: "The idea of evolution by natural selection is a matter of logic, not science, and it follows that the concept of evolution by natural selection is not, strictly speaking, scientific". Certainly it is possible formally to deduce the conclusion that some natural selection must occur from two or three general propositions about multiplicative reproduction, variation, and the finitude of resources. But this neither disqualifies that conclusion as science nor turns it into an empty truth of logic. Substantial truths can be and are deduced with perfect formal validity from premises stating other similarly substantial truths.

ANTONY FI.EW

Department of Philosophy,

University of Reading, UK

\section{Defining a lectin}

SIR - The Nomenclature Committee of the International Union of Biochemistry has discussed the objections raised by Kocourek and Hořejši ${ }^{1}$ to the definition of lectins proposed by Goldstein et al. ${ }^{2}$ which was also published by the Nomenclature Committee in its 1981 Newsletter $^{3}$.

According to both definitions, "a lectin is a sugar-binding protein of non-immune origin" (glycoproteins are a class of proteins and there is no need to specify them in the definition). The emphasis in the definition of Goldstein $e t$ $a l$. is an operational one, so the definition is easy to apply experimentally by the criteria of agglutination of cells (not necessarily of erythrocytes, which carry a limited variety of sugars on their surface) or precipitation of glycoconjugates. By contrast, the criterion of Kocourek and Hořejši of lack of enzymatic activity is difficult to apply; for example, glycosyltransferase activity might be present with an acceptor different from those tested. Moreover, there is now evidence that certain proteins hitherto known as lectins possess glycosidase activity ${ }^{4}$.

The definition of Goldstein et al. implies the presence of more than one carbohydratebinding site. Strictly speaking, it excludes proteins such as ricin that are closely related to lectins in certain properties (for example, acid composition and possibly primary structure) and derived from the same plants, and this may be a disadvantage. Nevertheless the definitjon of Kocourek and Hořejší is so close to meaning "carbohydrate-binding protein" that a special name seems unnecessary, and the definition is too broad to be useful, since it includes substances such as sugar-transport proteins, chemotaxis receptors, certain bacterial toxins, hormones and interferons.

As long as we do not know with certainty the role of lectins, whether in plants, animals or microorganisms, it seems preferable to focus the definition of these substances on positive and easily testable properties. We therefore plan to continue to use the word as proposed by Goldstein et al.

H.B.F. Dixon (Secretary)

Nomenclature Committee of International Union of Biochemistry,

Cambridge, UK

1. Kocourek, J. \& Hořejší, V. Nature, News \& Views 290, 188 (1981).

2. Goldstein, 1.J., Hughes, R.C., Monsigny, M., Osawa, T. \& Sharon, N. Nature 285, 66 (1980).

3. Nomenciature Committee Archs Biochem. Biophys. 206, 458-462 (1981); Eur. J. Biochem. 114, 1-4 (1981); Hoppe-Seyler's Z. physiol. Chem. 362, I-IV (1981): J. biol. Chem. 256, 12-14 (1981)

4. Hankins, C.N. \& Shannon, L.M. J. biol. Chem. 253, 7791-7797 (1978); Pl. Physiol. 65, 618-622 (1980). 